\title{
EDITORIAL
}

\section{Continuing care and COVID-19: a Canadian tragedy that must not be allowed to happen again}

\author{
Jayna M. Holroyd-Leduc MD, Andreas Laupacis MD MSc
}

Cite as: CMAJ 2020 June 8;192:E632-3. doi: 10.1503/cmaj.201017; early-released May 14, 2020

$\mathbf{R}$ ecent estimates suggest that between $62 \%$ and $82 \%$ of deaths due to coronavirus disease 2019 (COVID-19) in Canada have occurred among residents of continuing care homes (which include nursing homes, long-term care and supportive living facilities). ${ }^{1,2}$ In Ontario, 5 of the 7 health care workers who have died from COVID-19 were personal support workers in continuing care homes. ${ }^{3}$ Reports of residents of such facilities being abandoned because of lack of staff are appalling. ${ }^{4}$

By any measure, what has happened in continuing care is a national tragedy. Although a high death rate from COVID-19 among residents of continuing care homes might be expected given their age, frailty and comorbidities, a death rate of such magnitude need not have occurred. As we address the current impact of COVID-19 in continuing care, we must ensure that we also address the underlying problems that COVID-19 has exposed within the sector.

Many deaths could have been prevented if the same amount of effort that was put into preparing the hospital sector for COVID19 (which so far seems to have been successful) had also been spent on preparing the continuing care sector. Measures that could have protected vulnerable residents and staff, such as mandating that support workers work in only 1 facility and instituting aggressive testing, were applied only after outbreaks had already begun. Facilities should have been supported to develop plans for where they would physically care for residents who tested positive for severe acute respiratory syndrome coronavirus 2 (SARSCoV-2) and how they would ensure social distancing among those with cognitive impairment. Failure to ensure an adequate supply of personal protective equipment (PPE) for continuing care homes, and lack of directives mandating its use in these environments where risk of infection is high, is indefensible.

Beneath the lack of pandemic preparedness for continuing care lie many systemic problems. Historically, Canadian society has undervalued the continuing care workforce, which consists mostly of racialized women who are underpaid for the important work they do. Personal support workers (or health care aides), who provide the day-to-day personal care, psychological support and other care needed by residents, can earn as little as $\$ 14$ per hour. Poor pay forces many to work shifts in several care homes in order to earn a living wage, which has contributed to the spread of SARS-CoV-2 across facilities. Many residents in continuing care share rooms, and staff are expected to care for more patients than they should, ${ }^{5}$ which presents obvious challenges to controlling the spread of infectious illness. Even before the COVID-19 pandemic, outbreaks of respiratory infections were common among continuing care residents, ${ }^{6}$ so the high rates of COVID-19 we have seen in this population should not be surprising.

Lack of coordination and collaboration between acute health care and continuing care in many provinces has contributed to a lack of PPE, shortages of SARS-CoV-2 testing supplies and staffing challenges within the latter facilities. Alberta is an exception, where the presence of a province-wide health system has enabled a more coordinated response to COVID-19 across the care continuum. ${ }^{7}$

After COVID-19, Canada's heath care systems will be forever changed. The tragic death toll among continuing care residents demands that the needs of this sector be at the top of the planning process, not at the bottom where they have traditionally been. A first step would be to implement more equitable pay for those working within continuing care. Recently, the BC government has responded by paying all continuing care workers the same wages as unionized care workers employed within public health authority-run facilities ( $\$ 24.83 / \mathrm{h}$ starting wage). ${ }^{8}$ It remains to be seen whether this change will be made permanent or spread across the country. Pay equity should be accompanied by the addition of staff and allowances for more person-centred approaches that provide better care for residents with increasingly complex medical, cognitive and functional needs. ${ }^{5}$ Personcentred care includes increasing opportunities for meaningful interactions and activities, empowering staff, and promoting a home (not institutional) environment. ${ }^{9}$

Changes to the design and built environment of continuing care facilities is also important in order to improve the quality of life for those living and working in them. ${ }^{10}$ Opportunities exist to develop and incorporate novel technologies that are specifically designed for the continuing care context, which can help better support social interaction and medical monitoring in times of 
needed social distancing. New standards for building size and room designs that support quality of life, even when social distancing is needed, should be implemented.

The premature deaths of the people in continuing care, whom we failed to protect from COVID-19, should be a call to action. They built this country. They deserved better, as do those currently living and working in continuing care.

\section{References}

1. Comas-Herrera A, Zalakaín J, Litwin C, et al. Mortality associated with COVID-19 outbreaks in care homes: early international evidence. London (UK): International Long-Term Care Policy Network; 2020. Available: https://tccovid.org/wp-content/ uploads/2020/05/Mortality-associated-with-COVID-3-May-final-5.pdf (accessed 2020 May 11).

2. MacCharles T. $82 \%$ of Canada's COVID-19 deaths have been in long-term care, new data reveals. The Star 2020 May 7. Available: www.thestar.com/politics/ federal/2020/05/07/82-of-canadas-covid-19-deaths-have-been-in-long-term-care .html (accessed 2020 May 11).

3. Aguilar B. Fifth Ontario personal support worker dies after contracting COVID-19. CTV News [Toronto] 2020 May 7, updated 2020 May 8. Available: https://toronto. ctvnews.ca/fifth-ontario-personal-support-worker-dies-after-contracting-covid-19 -1.4930176 (accessed 2020 May 11).

4. Horrors revealed at virus-hit Canada nursing home. The Japan Times 2020 Apr. 19. Available: www.japantimes.co.jp/news/2020/04/19/world/coronavirus -canada-nursing-home/\#.Xq2JiahKg2w (accessed 2020 May 11).
5. Hire more staff. Toronto: Ontario Long Term Care Association; 2019. Available: www.betterseniorscare.ca/hire-more-staff/ (accessed 2020 May 12).

6. Childs A, Zullo AR, Joyce NR, et al. The burden of respiratory infection among older adults in long-term care: a systemic review. BMC Geriatr 2019;19:210.

7. Millar A, Hanson H, Wagg A, et al.; Seniors Health Strategic Clinical Network. Seniors Health Strategic Clinical Network: age proofing Alberta through innovation. CMAJ 2019;191(Suppl):S19-21.

8. Order of the Minister of Public Safety and Solicitor General: Emergency Program Act. Ministerial Order No. M105. Province of British Columbia; 2020 Apr. 10. Available: www2.gov.bc.ca/assets/gov/public-safety-and-emergency-services/ emergency-preparedness-response-recovery/gdx/orders-april-10/ep_act_order _m105-2020_single_site.pdf (accessed 2020 May 12).

9. Brownie S, Nancarrow S. Effects of person-centered care on residents and staff in aged-care facilities: a systematic review. Clin Interv Aging 2013;8:1-10.

10. Fleming R, Bennett KA. Environmental design resources. In: Dementia Training Australia. Osborne Park (Australia): Alzheimer's WA; 2017. Available: www. enablingenvironments.com.au/uploads/5/0/4/5/50459523/dta_intro_resource1 _digital.pdf (accessed 2020 May 12).

Competing interests: See www.cmaj.ca/site/misc/cmaj_staff.xhtml

Affiliations: Departments of Medicine and Community Health Sciences (Holroyd-Leduc), University of Calgary, Calgary, Alta.; editor-in-chief (Laupacis), CMAJ

Correspondence to: CMAJ editor, cmaj@cmajgroup.ca 